\title{
Synthesis of manganese oxide supported on mesoporous titanium oxide: Influence of the block copolymer
}

\author{
F. Schmit ${ }^{\mathrm{a}, \mathrm{b}}$, L. Bois ${ }^{\mathrm{a}, *}$, R. Chiriac ${ }^{\mathrm{a}}$, F. Toche ${ }^{\mathrm{a}}$, F. Chassagneux $^{\mathrm{a}}$, M. Besson ${ }^{\mathrm{b}}$, C. Descorme ${ }^{\mathrm{b}}$, \\ L. Khrouz ${ }^{\mathrm{c}}$ \\ a Laboratoire des Multimatériaux et Interfaces, UMR CNRS 5615, Bât. Berthollet, Université Claude Bernard-Lyon 1, 43 Bd 11 novembre 1918,69622 \\ Villeurbanne, France \\ b IRCELYON, Institut de recherches sur la catalyse et l'environnement de Lyon (UMR 5256 CNRS/Université Lyon 1), Lyon, France \\ ' ENS LYON Laboratoire de Chimie (LR6, site Monod), 46, allée d'Italie, 69364 Lyon Cedex 07, France
}

\begin{abstract}
Manganese oxides supported on mesoporous titanium oxides were synthesized via a sol-gel route using block copolymer self-assembly. The oxides were characterized by X-ray diffraction, infrared spectroscopy, thermal analyses, nitrogen adsorption/desorption, electron microscopy and electronic paramagnetic resonance. A mesoporous anatase containing amorphous manganese oxide particles could be obtained with a $0.2 \mathrm{Mn}$ :Ti molar ratio. At higher manganese loading ( $0.5 \mathrm{Mn}$ :Ti molar ratio), segregation of crystalline manganese oxide occurred. The influence of block copolymer and manganese salt on the oxide structure was discussed. The evolution of the textural and structural characteristics of the materials upon hydrothermal treatment was also investigated.
\end{abstract}

\section{Introduction}

The development of active and stable solid catalysts for oxidation reactions in water at relatively high temperature and pressure is an important challenge, especially in the field of water treatment. As mesoporous oxides have a high specific surface area, high porous volume and pore size about $10 \mathrm{~nm}$, they may have many advantages for the diffusion of molecules to be converted and so increase their interaction with the catalyst surface. Titania, used as a support, has been reported as stable under the reaction conditions of interest. Furthermore, transition metal oxides, including manganese oxide with many degrees of oxidation $(+2,+3,+4,+7)$ were demonstrated to have interesting oxidation properties [1-5].

Manganese oxides have been extensively studied as catalysts in gas phase oxidation reactions $[2,6-15]$ as well as in some selective reduction reactions [16-22]. They are also good candidates as catalysts in water treatment applications [23-25]. These oxides were evaluated in the catalytic wet air oxidation reaction when the elimination of organic pollutants occurs in the liquid phase using oxygen as the oxidant [3,26-31]. Another important application for manganese oxides is as electrode materials [32]. However, in this

\footnotetext{
* Corresponding author.

E-mail address: laurence.bois@univ-lyon1.fr (L. Bois).
}

article we focus our attention on the one pot synthesis of manganese oxides supported on mesoporous titania.

Manganese oxides are conventionally obtained either by oxidation of manganese(II) salts by $\mathrm{KMnO}_{4}$ or by reduction of $\mathrm{KMnO}_{4}$ by organic reagents [4]. Such oxides are often very porous but demonstrate limited thermal stability under the reaction conditions of interest. New synthetic methods have been developed for the elaboration of better nano-structured manganese oxides. One approach to synthesize nano-structured manganese oxides is the block copolymer self-assembly method, which has often been implemented with the objective of producing mesoporous oxides. This methodology is used to obtain oxides with high specific surface areas and well-defined porous structures. In fact, block copolymers form micelles with a hydrophobic core (consisting of polypropylene oxide chains) and a hydrophilic shell (consisting of polyethylene oxide chains). Single oxides may crystallize around these micelle assemblies. The polymer elimination leads to an oxide with a high mesoporosity. Using such a process, $\mathrm{MnO}_{2}$ can be obtained with a specific surface area around $200 \mathrm{~m}^{2} \mathrm{~g}^{-1}$ [13,33-42]. A mesoporous titania could also be easily prepared using the same procedure [43]. However, among the studies devoted to the elaboration of binary Mn-Ti oxides [44-50], very few reported the use of the self-assembly method [44]. Solid solutions of $\mathrm{Mn}$ in anatase were often reported [49-52], but binary oxides such as $\mathrm{Mn}_{2} \mathrm{TiO}_{4}$ and $\mathrm{MnTiO}_{3}$ were also observed at high temperature [51-53]. For such bimetallic systems, the relative 
localization of the two components is always a matter of discussion. Stoichiometric binary oxides, solid solutions or mixtures of simple oxides are obtained. From the catalytic application point of view, the accessibility of the active phase is the key point.

In this paper, we describe the synthesis of mixed manganese and titanium oxides using the self-assembly process with a polyethylene oxide-polypropylene oxide block copolymer. Our attention focuses on the influence on the material structure of (i) the presence of the block copolymer and (ii) the nature of the manganese salt used as the precursor. Block copolymers have been shown to form complexes with metal cations [54-56]. Manganese oxide could be introduced either inside the titania walls or at the titania surface by choosing a good manganese precursor having more or less affinity either with the polymer and/or with the titania sol.

\section{Experimental}

\subsection{Synthesis of the materials}

The titania gels were prepared following the method described by Ismail et al. [57]. $\mathrm{Ti}(\mathrm{OBu})_{4}\left(3.4 \mathrm{~g}, 10^{-2} \mathrm{~mol}\right)$ in ethanol $(25 \mathrm{~mL})$ was mixed with $1.6 \mathrm{~g}$ of Pluronic ${ }^{\circledR} \mathrm{F}-127$, a polyethylene oxidepolypropylene oxide-polyethylene oxide $\left(\mathrm{PEO}_{106}-\mathrm{PPO}_{70}-\mathrm{PEO}_{106}-\right.$ herein referred to as $\mathrm{P}$ ) block polymer, $2.3 \mathrm{~mL}$ of acetic acid and $0.74 \mathrm{~mL}$ of hydrochloric acid (37 wt\%). Manganese was incorporated in the titania sol in various proportions using $\mathrm{MnCl}_{2}, 4 \mathrm{H}_{2} \mathrm{O}$ or $\mathrm{Mn}$ (acetylacetonate) $)_{2}$ (referred to as $\mathrm{Mn}(\mathrm{acac})_{2}$ ). The Mn:Ti molar ratio was fixed at 0.2 or 0.5 . Colourless sols were rapidly obtained when the $\mathrm{MnCl}_{2}, 4 \mathrm{H}_{2} \mathrm{O}$ salt was used, while a yellow sol formed more slowly with $\mathrm{Mn}(\mathrm{acac})_{2}$. The sols were slowly evaporated until formation of a gel. The samples were thermally treated at $450{ }^{\circ} \mathrm{C}$ for $5 \mathrm{~h}$ (temperature ramp of $1{ }^{\circ} \mathrm{C} \mathrm{min}^{-1}$ ), and black powders were obtained. Finally, in order to assess their hydrothermal stability, the samples $\left(80 \mathrm{mg}\right.$ ) were put inside a $250 \mathrm{~mL}$ autoclave at $200{ }^{\circ} \mathrm{C}$ for $24 \mathrm{~h}$. Brown powders were systematically obtained after such hydrothermal treatment.

In the $\mathrm{TM}_{x y} \mathrm{P}_{z}$ samples, the subscripts $x, y, z$ and $h$ refer to the following:

- $x$ indicates the nature of the manganese salt $(\mathrm{Cl}$ for $\mathrm{MnCl}_{2} \cdot 4 \mathrm{H}_{2} \mathrm{O}$ and $\mathrm{A}$ for $\left.\mathrm{Mn}(\mathrm{acac})_{2}\right) . x$ is omitted when the solid did not contain manganese.

- $y$ indicates the theoretical Mn:Ti molar ratio. $y$ is 0 when the solid did not contain any manganese.

$-z$ indicates the amount of block copolymer introduced in the preparation ((0) $0 \mathrm{~g}$, (1) $0.8 \mathrm{~g}$, (2) $1.6 \mathrm{~g}$, (3) $3.2 \mathrm{~g}) . z$ is omitted whenever the solid contained a $1.6 \mathrm{~g}$ polymer proportion.

- Finally, if the sample had been hydrothermally treated, an $\mathrm{h}$ is introduced at the end of the sample reference (e.g. $\mathrm{TM}_{x y} \mathrm{P}-\mathrm{h}$ ).

\subsection{Characterization}

X-ray diffraction (XRD) patterns were recorded on a PANalytical Xpert Pro diffractometer equipped with a monochromator, using $\mathrm{CuK} \alpha$ radiation $(1.54 \AA$ ). The sample texture was also analyzed via nitrogen adsorption/desorption using a Sorptomatic 1990 (CE Instruments, Milan, Italy). Prior to analysis, the samples were degassed under vacuum at $70{ }^{\circ} \mathrm{C}$ for $4 \mathrm{~h}$.

The specific surface area was determined using the BrunauerEmmett-Teller (BET) method. The average pore size $\left(d_{\text {mean }}\right)$ and the mesoporous volume were calculated from the adsorption curve of the isotherm using the Barrett-Joyner-Halenda (BJH) method. FTIR spectra were recorded on a SAFAS instrument using $\mathrm{KBr}$ pellets.

Thermogravimetric analyses with a simultaneous differential thermal analysis signal were performed on a TGA/SDTA Mettler Toledo 851 apparatus. The sample $(20 \mathrm{mg}$ ) was introduced in an aluminum crucible and the temperature was increased to $500{ }^{\circ} \mathrm{C}$ at $10{ }^{\circ} \mathrm{C} \mathrm{min}^{-1}$. Air was used as the reactive gas $\left(50 \mathrm{~mL} \mathrm{~min}^{-1}\right)$. For $\mathrm{TM}_{x 0.2} \mathrm{P}$ and $\mathrm{TM}_{X 0.2} \mathrm{P}_{0}$, the temperature was increased to $1200{ }^{\circ} \mathrm{C}$ at $20{ }^{\circ} \mathrm{C} \mathrm{min}^{-1}$. Relatively broad signals were obtained due to the high heating rate.

DSC analyses were performed on a DSC1 Mettler-Toledo apparatus. The solid to be analyzed (ca. $10 \mathrm{mg}$ ) was placed in a $40 \mu \mathrm{L}$ aluminum pan, with a pierced lid and sealed before introduction into the DSC cell. Each analysis consisted of two steps. First, the temperature was increased to $500{ }^{\circ} \mathrm{C}\left(10^{\circ} \mathrm{C} \mathrm{min}-1\right)$ before cooling down to room temperature. Then, air was used as the reactive gas $\left(30 \mathrm{~mL} \mathrm{~min}^{-1}\right)$. Additional DSC experiments were also performed up to $700{ }^{\circ} \mathrm{C}\left(20^{\circ} \mathrm{C} \mathrm{min}{ }^{-1}\right)$ on the $\mathrm{TM}_{x y} \mathrm{P}$ samples. SEM images were acquired on an $\mathrm{S} 800$ Hitachi microscope operated at $15 \mathrm{kV}$.

TEM images were obtained on a Topcon instrument operated at $200 \mathrm{kV}$. Before observation, the samples were ground and deposited on a copper grid covered with a holey carbon film.

EPR experiments on the $\mathrm{TM}_{\mathrm{Cl} 0.2} \mathrm{P}$ sample were done using an $\mathrm{X}$-band spectrometer (Bruker EMX plus, double mode) and an X-band $(9.4 \mathrm{GHz})$ Bruker ESP 500E spectrometer using a standard rectangular cavity. Simulation of the spectra was realized with "easyspin" (Matlab toolbox). The experimental spectra were simulated using the following parameters: frequency, $9.64 \mathrm{GHz}$; temperature, $70 \mathrm{~K}$; microwave power, $6.41 \mathrm{~mW}$; amplitude modulation $5 \mathrm{G}$; and modulation frequency, $100 \mathrm{kHz}$.

\section{Results}

\subsection{XRD results}

The $\mathrm{TM}_{x 0.2} \mathrm{P}$ samples with the lowest Mn:Ti ratio (0.2) and synthesized in the presence of a medium proportion ( $1.6 \mathrm{~g}$ ) of block copolymer, were characterized by XRD (Fig. 1a). The XRD pattern of the reference sample prepared without addition of any manganese salt $\left(\mathrm{TM}_{0} \mathrm{P}\right)$ was characteristic of the anatase phase of $\mathrm{TiO}_{2}$ (ICDD no. 01-084-1285). Upon addition of manganese $\left(\mathrm{TM}_{\mathrm{ClO} .2} \mathrm{P}\right.$ and $\left.\mathrm{TM}_{\mathrm{A} 0.2} \mathrm{P}\right)$, the diffraction patterns showed a less crystalline anatase $\mathrm{TiO}_{2}$ phase, with a shift of the $\left(\begin{array}{lll}0 & 0 & 4\end{array}\right)$ reflection line towards higher diffraction angles (see insert on Fig. 1a). Such a shift had already been seen in the case of the $\mathrm{Mn}-\mathrm{Ti}-\mathrm{O}$ system and attributed to the substitution of $\mathrm{Mn}^{4+}$ (ionic radius $0.67 \AA$ ) for $\mathrm{Ti}^{4+}$ (ionic radius $0.68 \AA$ ) [49-50]. Furthermore, the $\left(\begin{array}{lll}1 & 0 & 5\end{array}\right)$ and (2 11 1) reflections initially observed at $53.9^{\circ}$ and $55.0^{\circ}$, respectively, merged. Finally, no crystallization of any manganese oxide was detected.

To determine the influence of the presence of the block copolymer on the synthesis, reference samples $\left(\mathrm{TM}_{x 0.2} \mathrm{P}_{0}\right)$ synthesized without addition of any block copolymer were studied (Fig. 1b). When no manganese was added to the preparation $\left(\mathrm{TM}_{0} \mathrm{P}_{0}\right)$, the diffraction pattern was characteristic of the anatase phase (A, ICDD no. 01-084-1285) as in the case of the $\mathrm{TM}_{0} \mathrm{P}$ sample when a medium proportion of block copolymer was used. However, a higher degree of crystallization was observed. When the $\mathrm{MnCl}_{2} \cdot 4 \mathrm{H}_{2} \mathrm{O}$ precursor was used $\left(\mathrm{TM}_{\mathrm{Clo} .2} \mathrm{P}_{0}\right)$, the diffraction pattern showed the formation of a very well crystallized $\mathrm{Mn}_{2} \mathrm{O}_{3}$ bixbyite phase (bx, ICDD 01-089-2809), while crystallization of the $\mathrm{TiO}_{2}$ anatase phase decreased in comparison with the solids synthesized in the presence of Pluronic ${ }^{\circledR}$ F-127, with the same Mn precursor. In the presence of the $\mathrm{Mn}(\mathrm{acac})_{2}$ precursor $\left(\mathrm{TM}_{\mathrm{A0.2}} \mathrm{P}_{0}\right)$, 

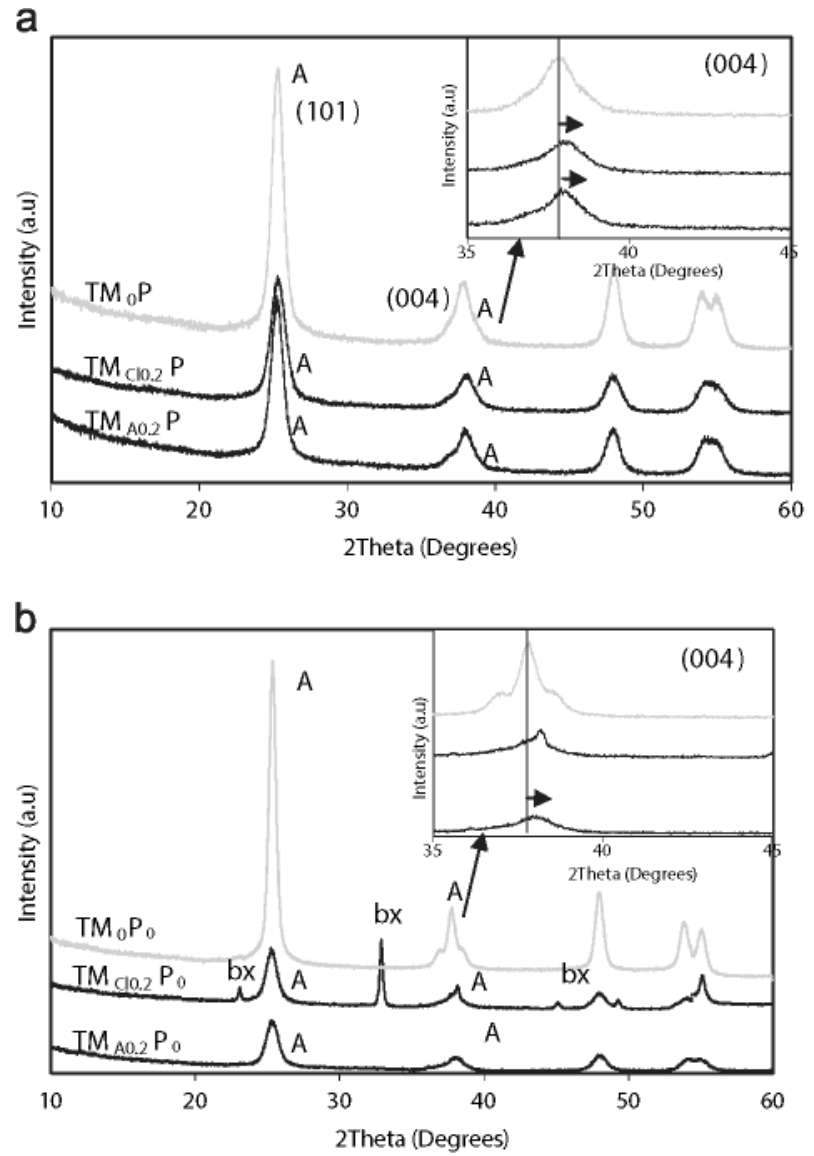

Fig. 1. X-ray diffraction patterns of $\mathrm{TM}_{x 0.2} \mathrm{P}(\mathrm{a})$ and $\mathrm{TM}_{x 0.2} \mathrm{P}_{0}$ (b) samples. A: anatase, bx: bixbyite.

the anatase phase was the only one detected. However, a shift of the $\left(\begin{array}{lll}0 & 0 & 4\end{array}\right)$ diffraction line was observed.

In the second step, samples with a higher Mn:Ti ratio (0.5) were (i) synthesized using the medium block copolymer ratio $\left(\mathrm{TM}_{x 0.5} \mathrm{P}\right)$ and (ii) analyzed by XRD (Fig. 2a). When the $\mathrm{MnCl}_{2}$, $4 \mathrm{H}_{2} \mathrm{O}$ precursor was used $\left(\mathrm{TM}_{\mathrm{Cl} 0.5} \mathrm{P}\right)$, the XRD characterization revealed the presence of the anatase $\mathrm{TiO}_{2}$ phase together with the bixbyite $\mathrm{Mn}_{2} \mathrm{O}_{3}$ (bx), and the $\mathrm{Mn}_{5} \mathrm{O}_{8}$ manganese oxide phases ( $\mathrm{m}$, ICDD no. 00-39-1218). With the $\mathrm{Mn}(\mathrm{acac})_{2}$ precursor $\left(\mathrm{TM}_{\mathrm{A0} .5} \mathrm{P}\right)$, the anatase crystallization drastically decreased. In turn, low crystalline rutile (R, ICDD no. 01-089-4920) and brookite phases (B, ICDD no. 01-076-1934) appeared. In addition, a $\mathrm{MnO}_{2}$ ramsdellite phase (q, ICDD no. 00-042-1316) was detected.

To assess the influence of the block polymer on the $\mathrm{MnCl}_{2} \cdot 4 \mathrm{H}_{2} \mathrm{O}$ precursor dispersion, the amount of Pluronic ${ }^{\circledR} \mathrm{F}$ 127 was varied (Fig. 2b). With the highest block copolymer proportion $\left(\mathrm{TM}_{\mathrm{ClO} .5} \mathrm{P}_{\mathrm{h}}\right)$, the bixbyite phase appeared to be poorly crystalline (by XRD analysis), while traces of a new $\mathrm{Mn}_{5} \mathrm{O}_{8}$ phase (m) were detected. On the contrary, with the lowest block copolymer proportion $\left(\mathrm{TM}_{\mathrm{Cl0} .5} \mathrm{P}_{1}\right)$, the bixbyite phase reflection line at $33.0^{\circ}$ became more intense. In fact, the higher the block copolymer concentration, the more difficult the manganese oxide phase crystallization. The anatase phase crystallization state was also reduced.

To summarize the different XRD observations, we can say that:

- whatever the precursor, some of the manganese ions could substitute for the titanium ions and also insert into the anatase lattice, as revealed by the shift of the $(004)$ reflection line.

- the block copolymer allowed the dispersion of the $\mathrm{MnCl}_{2} \cdot 4 \mathrm{H}_{2} \mathrm{O}$ salt even at the $0.2 \mathrm{Mn}$ :Ti ratio. In the absence of the block a

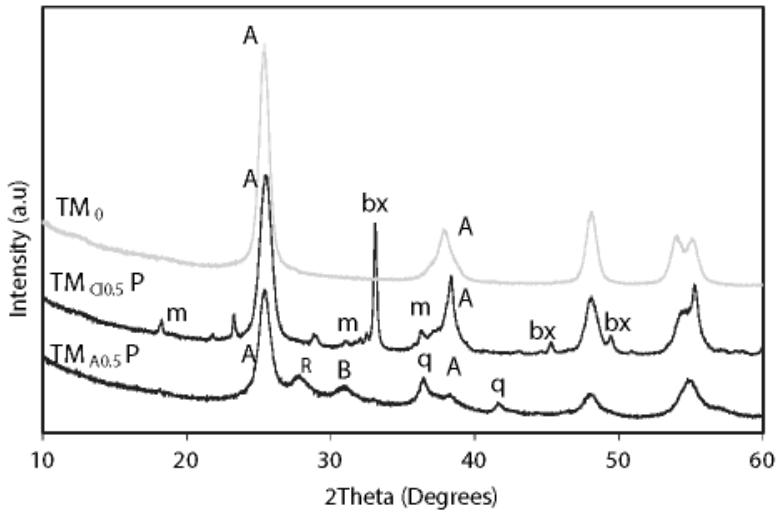

b

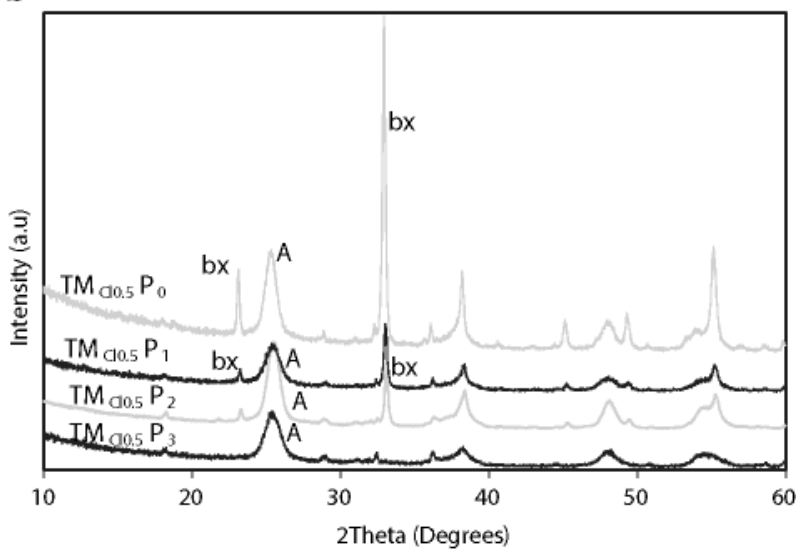

Fig. 2. (a) XRD patterns of the $\mathrm{TM}_{x 0.5} \mathrm{P}$ samples. $\mathrm{A}$ : anatase, $\mathrm{R}$ : rutile, $\mathrm{B}$ : brookite, bx: bixbyite, $\mathrm{m}: \mathrm{Mn}_{5} \mathrm{O}_{8}, \mathrm{q}: \mathrm{MnO}_{2}$ (ramsdellite). (b) XRD patterns of the $\mathrm{TM}_{\mathrm{Cl} 0.5} \mathrm{P}_{\mathrm{z}}$ samples with different polymer/Ti ratios.

copolymer, manganese mostly crystallized outside the titania network as a bixbyite phase $\left(\mathrm{Mn}_{2} \mathrm{O}_{3}\right)$.

- the block copolymer delayed anatase crystallization.

- the $\mathrm{Mn}(\mathrm{acac})_{2}$ precursor was dispersed in the titanium oxide even without the block copolymer and no manganese oxide crystallization was observed.

\subsection{FTIR}

The FTIR spectra of $\mathrm{TM}_{x 0.2} \mathrm{P}$ and $\mathrm{TM}_{x 0.2} \mathrm{P}_{0}$ samples showed a broad vibration band between 500 and $700 \mathrm{~cm}^{-1}$ (Fig. 3), except for the $\mathrm{TM}_{\mathrm{ClO} .2} \mathrm{P}_{0}$ sample, where well-defined vibration bands appeared at $655,600,570,520$ and $500 \mathrm{~cm}^{-1}$. The latter are characteristic of the $\mathrm{Mn}_{2} \mathrm{O}_{3}$ bixbyite phase [60]. In agreement with the XRD results, these observations confirmed that (i) the crystallization of the $\mathrm{Mn}_{2} \mathrm{O}_{3}$ phase occurred when the $\mathrm{MnCl}_{2}, 4 \mathrm{H}_{2} \mathrm{O}$ precursor was used, (ii) the crystallization of manganese oxide did not occur when Mn (acac) $)_{2}$ was used and (iii) the crystallization of the $\mathrm{Mn}_{2} \mathrm{O}_{3}$ phase was delayed in the presence of the block copolymer.

\subsection{Thermal analyses}

In order to better understand the interaction between the manganese salts and the block copolymer, thermal analyses were performed. DSC and TGA/SDTA experiments were carried out on the pure manganese salts, the pure block copolymer and mixtures of the different manganese salts with the block copolymer ( $1 \mathrm{~g}$ of 

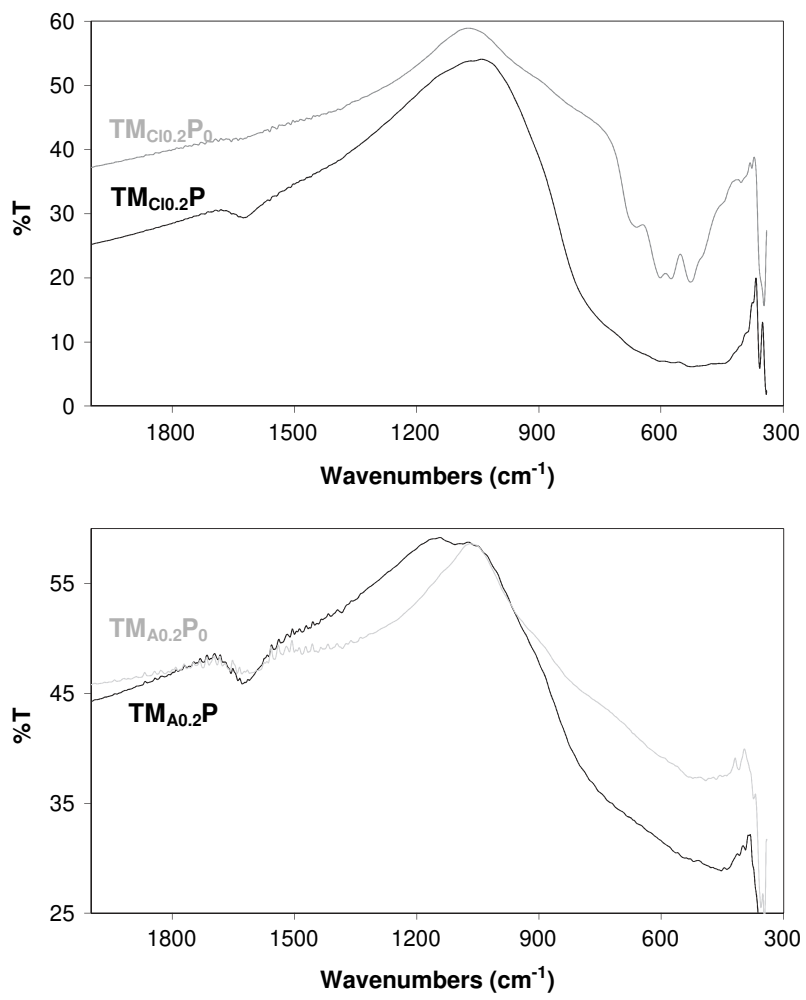

Fig. 3. FTIR spectra of the $\mathrm{TM}_{x 0.2} \mathrm{P}$ and $\mathrm{TM}_{x 0.2} \mathrm{P}_{0}$ samples.

manganese salt for $2 \mathrm{~g}$ of polymer). Mixtures were dissolved in ethanol before drying in order to observe the melting behaviour.

DSC thermograms of the pure compounds are given in Fig. 4a. For the block copolymer alone, two signals appeared. The first was an endothermic peak ca. $55{ }^{\circ} \mathrm{C}$, characteristic of the polymer melting; while the second starting from $150{ }^{\circ} \mathrm{C}$ was due to the exothermic degradation of the polymer. The thermogram of the $\mathrm{MnCl}_{2} \cdot 4 \mathrm{H}_{2} \mathrm{O}$ salt showed three endothermic peaks, with onset temperatures at $58{ }^{\circ} \mathrm{C}, 110{ }^{\circ} \mathrm{C}$ and $170{ }^{\circ} \mathrm{C}$, corresponding to one melting and two dehydration steps, respectively. In turn, for the $\mathrm{Mn}(\mathrm{acac})_{2}$ salt, a multi-step exothermic signal starting from $213{ }^{\circ} \mathrm{C}$ was observed. This was attributed to the degradation of the salt.

For the mixture of Pluronic ${ }^{\circledR} \mathrm{F}-127$ and $\mathrm{MnCl}_{2} \cdot 4 \mathrm{H}_{2} \mathrm{O}$ (Fig. 4b), the degradation process was characterized by a single exothermic signal starting at $160{ }^{\circ} \mathrm{C}$. The signals characteristic of the block copolymer alone and the manganese salt alone completely disappeared. The thermogram of the mixture of $\mathrm{Mn}(\mathrm{acac})_{2}$ and the block copolymer showed both an endothermic process at $55{ }^{\circ} \mathrm{C}$ and an exothermic one ca. $190^{\circ} \mathrm{C}$. For the latter, the polymer melting process was partially preserved. The polymer melting temperature was unchanged in the presence of the salt, but the melting enthalpy of the polymer in the mixture compared to the polymer alone decreased by $10 \%$, compared to the polymer alone. We hypothesized that this decrease was due to the interaction of part of the polymer (ca. 10\%) with the manganese precursor. Furthermore, the degradation temperature of the mixture was systematically higher compared to the degradation temperature of the polymer alone.

To sum up, the DSC analyses showed that polymer melting was no longer observed when the polymer was mixed with $\mathrm{MnCl}_{2} \cdot 4 \mathrm{H}_{2} \mathrm{O}$. However, the melting phenomenon was still partly preserved in the presence of $\mathrm{Mn}(\mathrm{acac})_{2}$. This indicated that the polymer acts as a ligand for the $\mathrm{Mn}^{2+}$ ions in $\mathrm{MnCl}_{2} \cdot 4 \mathrm{H}_{2} \mathrm{O}$ salt, while the complexation is much weaker with $\mathrm{Mn}(\mathrm{acac})_{2}$. In the polymer-salt mixtures, the degradation temperatures were modified
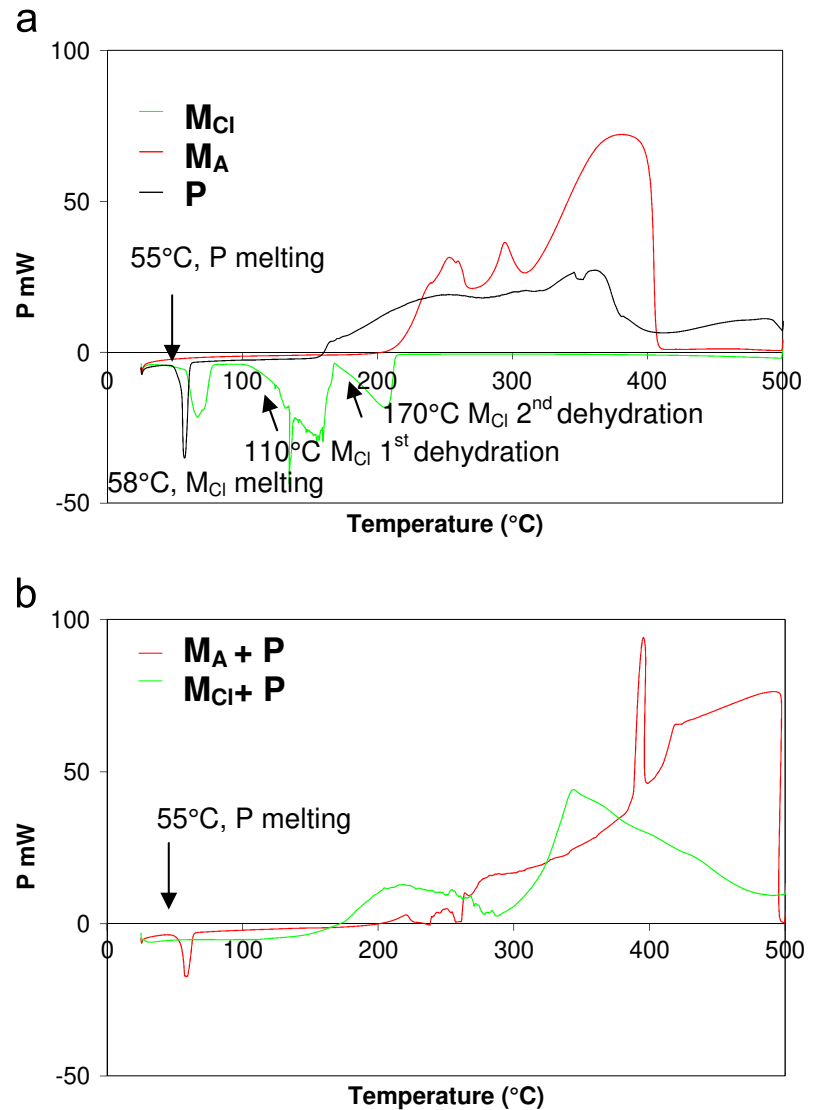

Fig. 4. DSC analyses of the pure manganese salts and the manganese salt-block copolymer mixtures.

compared to the pure compounds and appeared to be delayed in the case of $\mathrm{Mn}(\mathrm{acac})_{2}$ [61].

TGA with simultaneous differential thermal analysis (TGA-SDTA) was also done to investigate the decomposition processes in more detail (Fig. 5). We found that for the pure $\mathrm{MnCl}_{2}, 4 \mathrm{H}_{2} \mathrm{O}$ salt, the SDTA profile (Fig. 5b) showed an endothermic reaction around $60{ }^{\circ} \mathrm{C}$, which could be attributed to the melting process since there was no associated loss of mass (Fig. 5a). The two subsequent endothermic SDTA signals at 150 and $210{ }^{\circ} \mathrm{C}$ were assigned to the two major dehydration processes leading to $\mathrm{MnCl}_{2}$ (identified by XRD) as observed on the TGA curve ( 3 and $1 \mathrm{~mol}$ of $\mathrm{H}_{2} \mathrm{O}$ were lost respectively upon these two dehydration steps).

In the case of $\mathrm{Mn}(\mathrm{acac})_{2}$, the SDTA did not show any endothermic reaction. However, an exothermic reaction starting ca. $210{ }^{\circ} \mathrm{C}$ was attributed to the degradation process (Fig. 5b). This was in agreement with the TGA analysis (Fig. 5a) and the loss of mass observed from this temperature and above. In fact, the degradation process was incomplete at $500{ }^{\circ} \mathrm{C}$ and led to a mixture of $\mathrm{Mn}_{5} \mathrm{O}_{8}$ and $\mathrm{Mn}_{2} \mathrm{O}_{3}$ (identified with XRD).

For the block copolymer, the negative signal at about $50{ }^{\circ} \mathrm{C}$ (Fig. 5b) was attributed to melting since there was no associated loss of mass observed during the simultaneous TGA analysis (Fig. 5a). The degradation was characterized by the exothermic reaction between 200 and $400{ }^{\circ} \mathrm{C}$ and confirmed by TGA. Degradation of the polymer was found to be complete by $500{ }^{\circ} \mathrm{C}$.

For the mixture of the polymer with $\mathrm{MnCl}_{2} \cdot 4 \mathrm{H}_{2} \mathrm{O}$ (Fig. $5 \mathrm{~d}$ ), no signal could be attributed to any melting or dehydration phenomena. This was confirmed by the TGA results where the mass loss attributed to degradation started at a higher temperature compared to the pure polymer (Fig. 5c). However, melting was still detectable in the case of the polymer $\mathrm{Mn}(\mathrm{acac})_{2}$ mixture (Fig. 5d). However, the degradation 
a

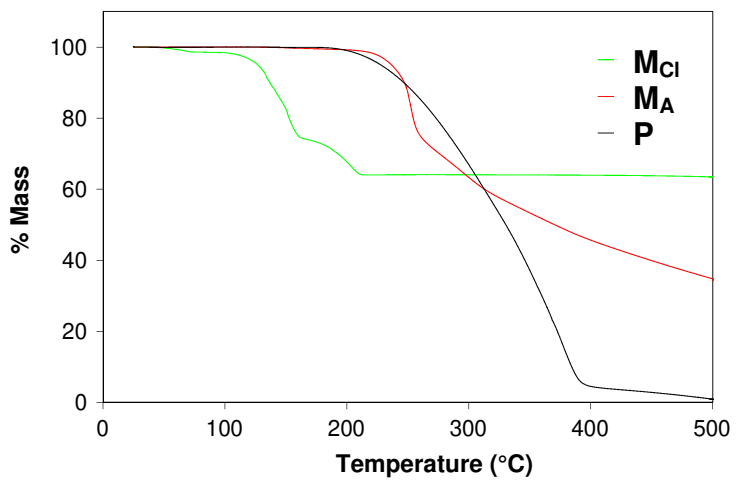

C

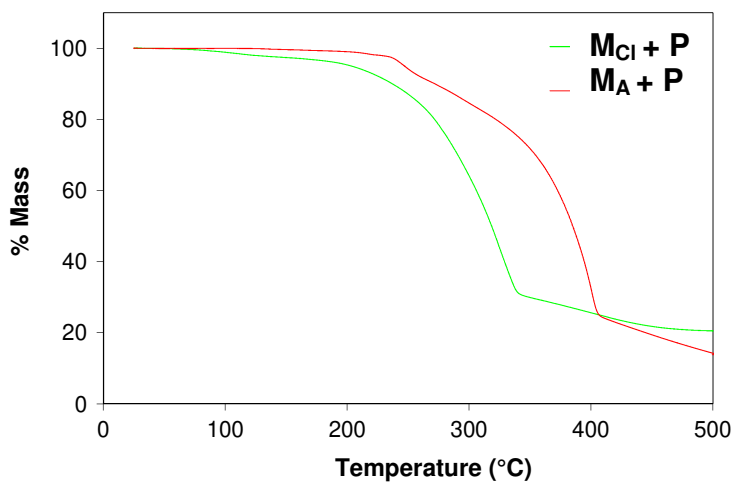

b

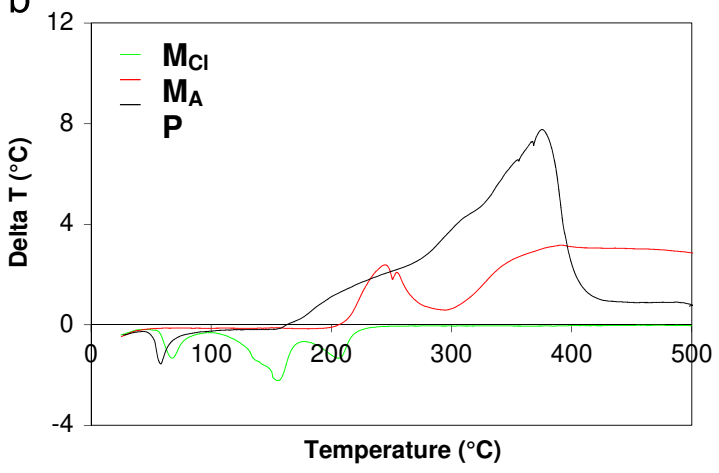

d

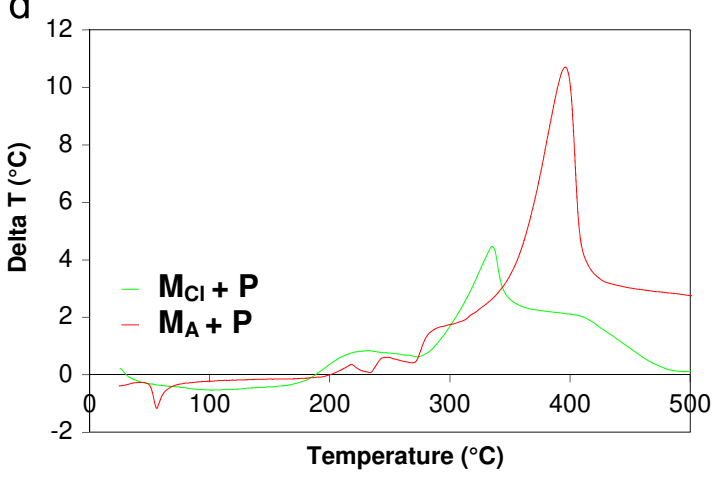

Fig. 5. TGA and SDTA analyses of the pure manganese salts and the manganese salt-block copolymer mixtures.

a

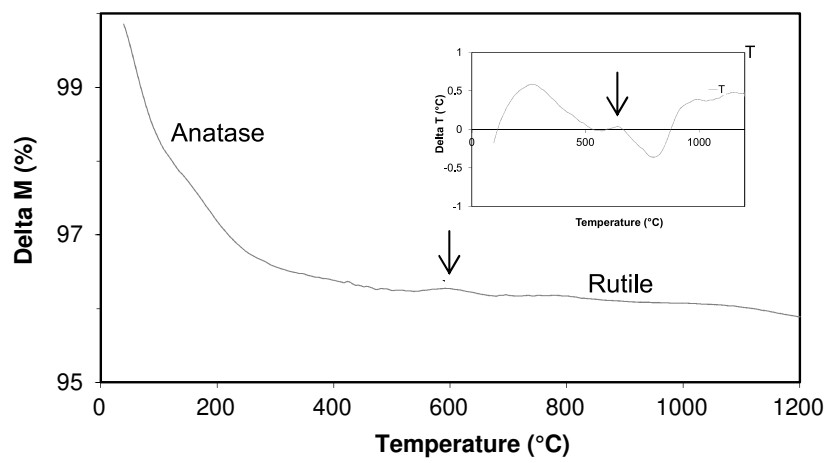

C

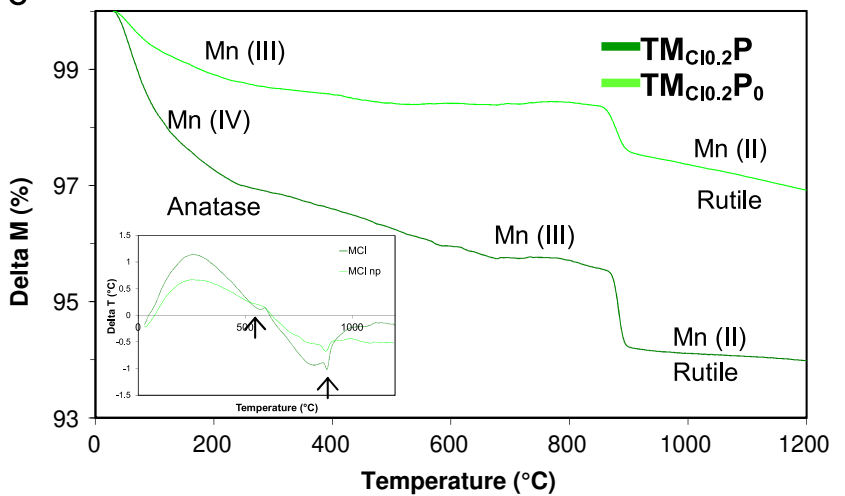

b

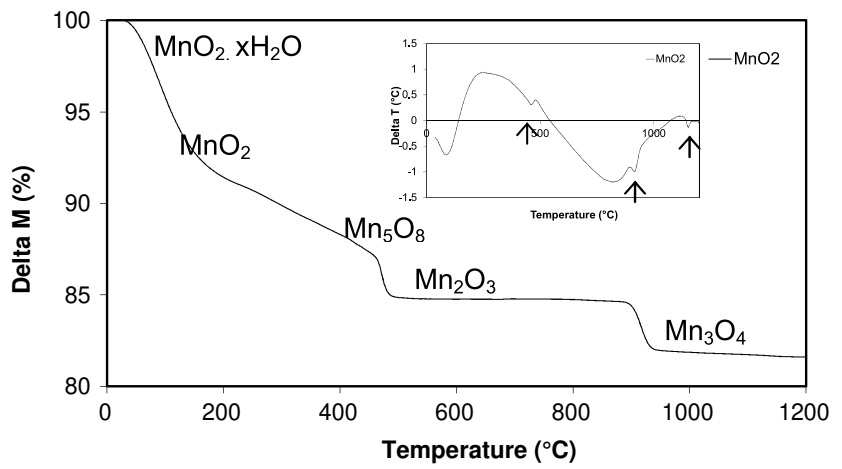

d

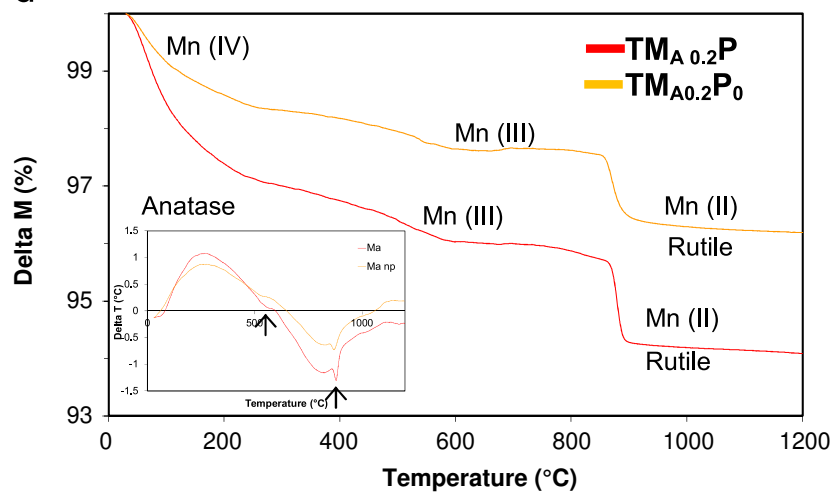

Fig. 6. DSC analyses of the $\mathrm{TM}_{x 0.2} \mathrm{P}$ and $\mathrm{TM}_{x 0.2} \mathrm{P}_{0}$ samples. 
process was also delayed at higher temperatures compared to the pure polymer, as in the previous case. Therefore, SDTA and TGA results confirmed the previous observations derived from the DSC analyses.

To follow the evolution of the degree of manganese oxidation upon heating, TGA-SDTA was also performed on different samples as well as on reference $\mathrm{TiO}_{2}$ and $\mathrm{MnO}_{2}$ samples after thermal treatment at $450{ }^{\circ} \mathrm{C}$ under air (Fig. 6). We observed that the transformation of the anatase phase to rutile was characterized by a small exothermic transition at $650{ }^{\circ} \mathrm{C}$ [62] (Fig. 6a). The $\mathrm{MnO}_{2}$ sample analysis showed (i) a dehydration step associated with the first weight loss; (ii) a second weight loss attributed to the reduction of $\mathrm{MnO}_{2}$ to a formula close to $\mathrm{Mn}_{5} \mathrm{O}_{8}$ (Fig. 6b); (iii) a third weight loss, associated with an endothermic peak around $450{ }^{\circ} \mathrm{C}$ corresponding to the formation of $\mathrm{Mn}_{2} \mathrm{O}_{3}$; (iv) a fourth weight loss, also associated with an endothermic phenomenon at around $900{ }^{\circ} \mathrm{C}$, related to the subsequent reduction of $\mathrm{Mn}_{2} \mathrm{O}_{3}$ to $\mathrm{Mn}_{3} \mathrm{O}_{4}$ and (v) a final endothermic transition at $1170{ }^{\circ} \mathrm{C}$ attributed to the transformation from $\alpha-\mathrm{Mn}_{3} \mathrm{O}_{4}$ to $\beta-\mathrm{Mn}_{3} \mathrm{O}_{4}$.

In the case of the two $\mathrm{M}_{\mathrm{Cl0} .2} \mathrm{P}$ and $\mathrm{TM}_{\mathrm{A} 0.2} \mathrm{P}$ samples, an initial weight loss around $100{ }^{\circ} \mathrm{C}$ was observed (Fig. 6c and d). This was attributed to water desorption from the pores due to the presence of the polymer, as in the case of the $\mathrm{TiO}_{2}$ sample (Fig. 6a). The second endothermic weight loss $\left(200-600^{\circ} \mathrm{C}\right)$ was attributed to the transformation of $\mathrm{Mn}$ (IV) species into $\mathrm{Mn}$ (III) $\left(\mathrm{Mn}_{2} \mathrm{O}_{3}\right)$. This second transition was barely observed in the case of the $\mathrm{TM}_{\mathrm{Cl} .2 .} \mathrm{P}_{0}$ sample, i.e. in the absence of polymer. A third weight loss also occurred at $900{ }^{\circ} \mathrm{C}$ for all samples, due to the transformation of some $\mathrm{Mn}(\mathrm{III})$ into $\mathrm{Mn}(\mathrm{II})$ species, upon crystallization of the $\mathrm{MnTiO}_{3}$ and $\mathrm{TiO}_{2}$ rutile phases. The latter reduction steps from $\mathrm{Mn}(\mathrm{IV})$ to $\mathrm{Mn}$ (III) and from $\mathrm{Mn}(\mathrm{III})$ to $\mathrm{Mn}$ (II) were more pronounced when the polymer was present. Similarly, when the block copolymer was used, a better agreement was found between the experimental and theoretical losses (1.6\%, Table 1). In these samples, manganese species were mainly present as Mn(IV), either included in a solid solution or as very well-dispersed amorphous $\mathrm{MnO}_{2}$. At $900{ }^{\circ} \mathrm{C}$, the conversion into $\mathrm{MnTiO}_{3}$ was rapid and complete. On the contrary, when no polymer was used in the synthesis, a large proportion of the manganese was present as Mn (III), with a lower reactivity upon transformation into $\mathrm{MnTiO}_{3}$. The TGA results proved that one of the major effects of the polymer was the stabilization of the Mn(IV) species, especially in the case of the $\mathrm{MnCl}_{2} \cdot 4 \mathrm{H}_{2} \mathrm{O}$ salt.

\subsection{Textural analyses}

The textural properties of the $\mathrm{TM}_{x 0.2} \mathrm{P}$ samples were characterized via nitrogen adsorption/desorption at liquid nitrogen temperature (Fig. 7). The results are summarized in Table 2. The isotherm of the pure titania $\mathrm{TM}_{0} \mathrm{P}$ sample was type IV, according to the IUPAC classification [63] and characteristic of a mesoporous material. The $\mathrm{H}_{2}$-type hysteresis loop is common in mesoporous material having a complex pore structure (differing from cylindrical-like pores) [63]. The specific surface area was $140 \mathrm{~m}^{2} \mathrm{~g}^{-1}$, pore volume $0.3 \mathrm{~cm}^{3} \mathrm{~g}^{-1}$

Table 1

Comparison of calculated and experimental weight losses between $800{ }^{\circ} \mathrm{C}$ and $1000{ }^{\circ} \mathrm{C}$.

\begin{tabular}{llll}
\hline & $\begin{array}{l}\text { Mn } \\
\text { precursor }\end{array}$ & $\begin{array}{l}\text { Calculated } \\
\text { wt loss (\%) }\end{array}$ & $\begin{array}{l}\text { Experimental } \\
\text { wt loss (\%) }\end{array}$ \\
\hline $\mathbf{T M}_{\mathbf{C 1 0 . 2}} \mathbf{P}$ & $\mathrm{MnCl}_{2}$ & 1.60 & 1.6 \\
$\mathbf{T M}_{\mathbf{C 1 0 . 2}} \mathbf{P}_{\mathbf{0}}$ & - & 1.65 & 1.1 \\
$\mathbf{T M}_{\mathbf{A 0 . 2}} \mathbf{P}$ & $\mathrm{Mn}(\mathrm{acac})_{2}$ & 1.61 & 1.6 \\
$\mathbf{T M}_{\mathbf{A 0 . 2}} \mathbf{P}_{\mathbf{0}}$ & - & 1.63 & 1.4 \\
\hline
\end{tabular}
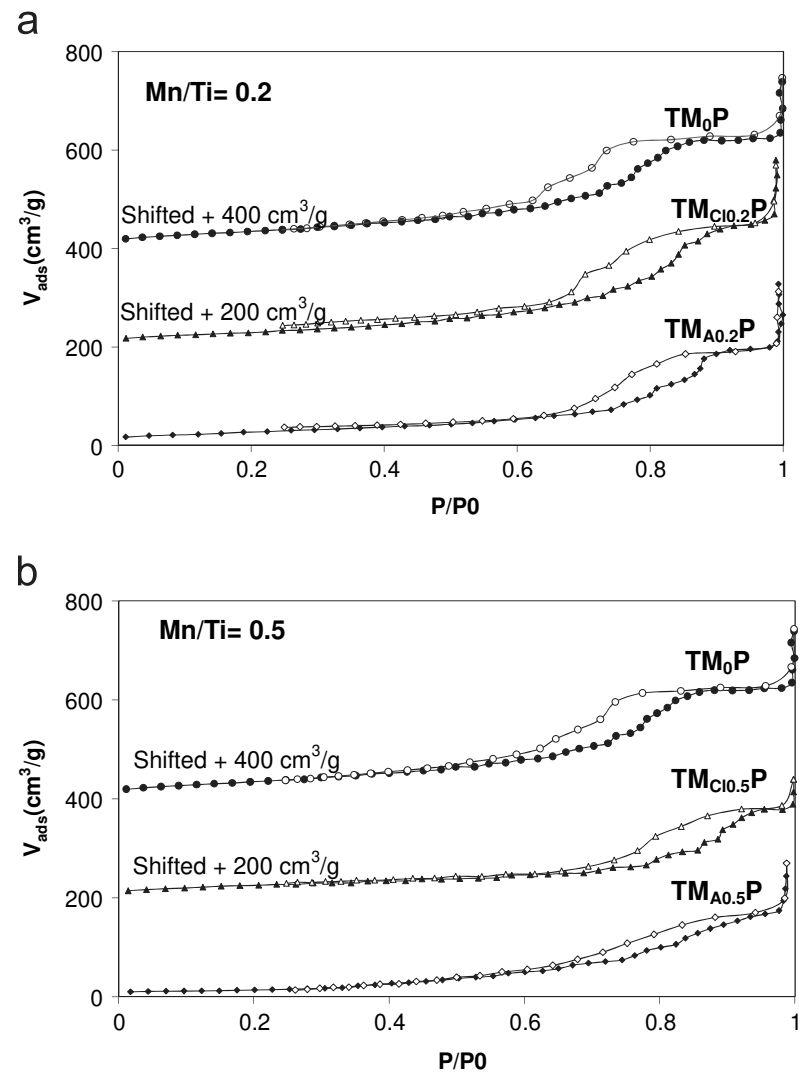

Fig. 7. Nitrogen adsorption/desorption isotherms of the $\mathrm{TM}_{x y} \mathrm{P}$ samples.

Table 2

Textural properties of $\mathrm{TM}_{x y} \mathrm{P}, \mathrm{TM}_{x 0.2} \mathrm{P}_{0}$ and $\mathrm{TM}_{x 0.2} \mathrm{P}-\mathrm{h}$ samples.

\begin{tabular}{|c|c|c|c|c|c|}
\hline & Mn:Ti & Mn precursor & $\begin{array}{c}\text { Specific } \\
\text { surface area } \\
\left(\mathbf{m}^{2} \mathbf{g}^{-1}\right)\end{array}$ & $\begin{array}{c}\text { Pore } \\
\text { volume } \\
\left(\mathrm{cm}^{3} \mathrm{~g}^{-1}\right)\end{array}$ & $\begin{array}{c}\text { Pore } \\
\text { diameter } \\
(\mathbf{n m})\end{array}$ \\
\hline $\mathbf{T M}_{\mathbf{0}} \mathbf{P}$ & $\mathbf{0}$ & - & 140 & 0.3 & 9 \\
\hline $\mathbf{T M}_{\mathrm{Cl} 10.2} \mathbf{P}$ & 0.2 & $\mathrm{MnCl}_{2}$ & 110 & 0.4 & 11 \\
\hline $\mathbf{T M}_{\mathbf{A} 0.2} \mathbf{P}$ & 0.2 & $\operatorname{Mn}(\mathrm{acac})_{2}$ & 100 & 0.3 & 12 \\
\hline $\mathbf{T M}_{\mathbf{C l 0 . 5}} \mathbf{P}$ & 0.5 & $\mathrm{MnCl}_{2}$ & 95 & 0.3 & 14 \\
\hline $\mathbf{T M}_{\mathbf{A} 0.5} \mathbf{P}$ & 0.5 & $\operatorname{Mn}(\mathrm{acac})_{2}$ & 50 & 0.3 & 10 \\
\hline $\mathbf{T M}_{\mathbf{0}} \mathbf{P}_{\mathbf{0}}$ & $\mathbf{0}$ & - & 85 & 0.3 & 11 \\
\hline $\mathbf{T M}_{\mathbf{C l} 0.2} \mathbf{P}_{\mathbf{0}}$ & 0.2 & $\mathrm{MnCl}_{2}$ & 30 & - & - \\
\hline $\mathbf{T M}_{\mathbf{A 0 . 2}} \mathbf{P}_{\mathbf{0}}$ & 0.2 & $\operatorname{Mn}(\mathrm{acac})_{2}$ & 95 & 0.1 & 6 \\
\hline $\mathrm{TM}_{\mathrm{Cl0.2}} \mathrm{P}-\mathrm{h}$ & 0.2 & $\mathrm{MnCl}_{2}$ & 170 & 0.4 & 11 \\
\hline $\mathrm{TM}_{\mathrm{A0.2}} \mathrm{P}-\mathrm{h}$ & 0.2 & $\operatorname{Mn}(\mathrm{acac})_{2}$ & 80 & 0.3 & 12 \\
\hline
\end{tabular}

and pore diameter $9 \mathrm{~nm}$. For the $\mathrm{TM}_{\mathrm{Cl0} .2} \mathrm{P}$ and $\mathrm{TM}_{\mathrm{A} 0.2} \mathrm{P}$ samples, the isotherms were also type IV (Fig. 7a). However, compared to pure titania, the specific surface area slightly decreased while the pore size increased (ca. $11 \mathrm{~nm}$ ). At higher manganese loading, i.e. at $0.5 \mathrm{Mn}$ :Ti molar ratio $\left(\mathrm{TM}_{x 0.5} \mathrm{P}\right.$, Fig. $\left.7 \mathrm{~b}\right)$, isotherms are still type IV, but the specific surface areas were even smaller.

To test the impact of Pluronic ${ }^{\circledR}$ F127 on the textural properties of the different samples, a series of samples were synthesized in the absence of any block copolymer $\left(\mathrm{TM}_{x 0.2} \mathrm{P}_{0}\right.$, Table 2). For the pure titanium dioxide sample $\left(\mathrm{TM}_{0} \mathrm{P}_{0}\right)$, a residual porosity was observed (specific surface area: $85 \mathrm{~m}^{2} \mathrm{~g}^{-1}$, pore volume: $0.3 \mathrm{~cm}^{3} \mathrm{~g}^{-1}$ ), probably due to the degradation of the organic part of the alkoxide precursor, behaving as a porogen agent [64]. For the mixed Mn-Ti oxides, the porosity collapsed completely in the case of manganese chloride salt $\left(\mathrm{TM}_{\mathrm{ClO} .2} \mathrm{P}_{0}\right)$ which is coherent with the XRD results and the crystallization of a bixbyite phase. In the 
case of the $\mathrm{Mn}(\mathrm{acac})_{2}$ precursor $\left(\mathrm{TM}_{\mathrm{A} 0.2} \mathrm{P}_{0}\right)$, the specific surface area was maintained, while the pore volume and pore size decreased. Therefore, we can conclude that whatever the manganese precursor, the absence of block copolymer induced a decrease in the porosity, and this was much more pronounced with $\mathrm{MnCl}_{2} \cdot 4 \mathrm{H}_{2} \mathrm{O}$.

\subsection{TEM and SEM observations}

TEM images of the samples prepared with the two different manganese precursors and a $0.2 \mathrm{Mn}$ :Ti molar ratio are shown on Fig. 8. A disordered porosity was observed in all cases. It seems that mesopores are formed by the aggregation of nanoparticles. On the high resolution TEM micrographs for the $\mathrm{TM}_{\mathrm{Cl}{ }_{2} \mathrm{P}} \mathrm{P}$ sample (Fig. 8c), some lattice fringes were seen with a spacing of $0.35 \mathrm{~nm}$, which is the expected distance for the (lllll 01 ) planes of anatase (A). In addition, a very thin layer around the anatase crystallites was noted which could be related to the presence of an amorphous manganese oxide at the surface. For the $\mathrm{TM}_{\mathrm{A0.2}} \mathrm{P}$ sample (Fig. $8 \mathrm{~d}$ ), no fringe characteristic of the (1 01 1) anatase planes was observed. However, fringes with $0.33 \mathrm{~nm}$ spacing were observed, as expected for the rutile $\left(\begin{array}{lll}1 & 1 & 0\end{array}\right)$ interplanar distance $(R)$. Some fringes with $0.34 \mathrm{~nm}$ spacing were also detected. Such fringes have already been reported in the literature and are suggested as being characteristic of the modification of the anatase phase crystallization induced by the presence of manganese [19].

The SEM pictures of the $\mathrm{TM}_{x 0.2} \mathrm{P}, \mathrm{TM}_{x 0.2} \mathrm{P}_{0}, \mathrm{TM}_{x 0.5} \mathrm{P}$ and $\mathrm{TM}_{x 0.5} \mathrm{P}_{0}$ samples are shown on Fig. 9. In the absence of any block copolymer and with the $\mathrm{MnCl}_{2} \cdot 4 \mathrm{H}_{2} \mathrm{O}$ salt, the manganese oxide phase segregation is clearly visible.

\subsection{EPR characterization}

In order to obtain more information on the manganese oxidation state, EPR characterizations were done on the $\mathrm{TM}_{\mathrm{Cl0.2}} \mathrm{P}$ sample (not a new paragraph). The evolution of the resonance peaks as a function of temperature is shown on Fig. 10a. Two major peaks (resonances) are clearly observed at $T=70 \mathrm{~K}$. The broader one was attributed to $\mathrm{Mn}(\mathrm{IV})$ species with strong interactions between them, i.e. $\mathrm{Mn}$ in a cluster type environment [65-68]. In turn, the narrower peak was attributed to isolated $\mathrm{Mn}(\mathrm{IV})$, localized at the outer surface of the $\mathrm{TiO}_{2}$ support. Furthermore, the hyperfine structure of the latter resonance peak observed at room temperature $\left(a_{\mathrm{av}} \sim 95 \mathrm{G}, g_{\mathrm{av}} \sim 2\right.$, Fig. 10a) was characteristic of the insertion of some $\mathrm{Mn}(\mathrm{II})$ ions inside the distorted $\mathrm{TiO}_{2}$ anatase lattice $[46,67]$. However, both the fast disappearance of these two major components in perpendicular mode at high temperature (Fig. 10a) and the presence of a resonance peak at $\mathrm{g} \sim 4$, in parallel mode (Fig. 10b), would indicate the predominance of $\mathrm{Mn}$ (IV) ions.

The EPR spectrum acquired at $70 \mathrm{~K}$ in perpendicular mode (Fig. 10c) was simulated using the following parameters:

$-S=3 / 2, g=[2.18,1.95,1.83], D=0.0433 \mathrm{~cm}^{-1}, E / D=0.33$, for isolated $\mathrm{Mn}(\mathrm{IV})$ ions;

- $S=1 / 2$ (intermediate spin state of $\operatorname{Mn}($ IV) ), $g=[1.97,1.96,1.95]$ for $\mathrm{Mn}$ in clusters.

The results were used to estimate the proportion of the different manganese species (Fig. 10d): $70 \%$ of the $\mathrm{Mn}(\mathrm{IV})$ ions were shown to be in a cluster-type environment and 30\% as isolated $\mathrm{Mn}(\mathrm{IV})$ ions covering the titania surface. a

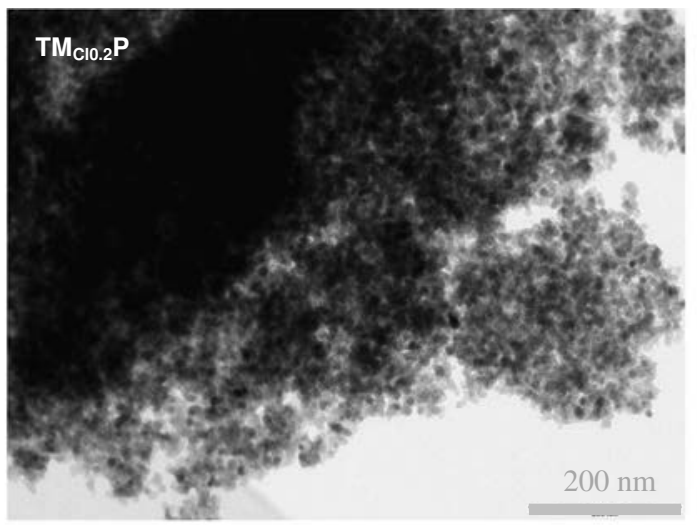

C

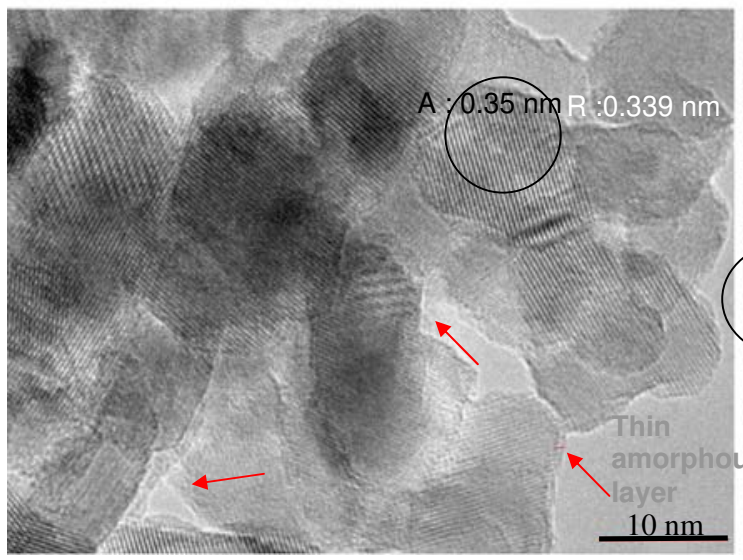

b

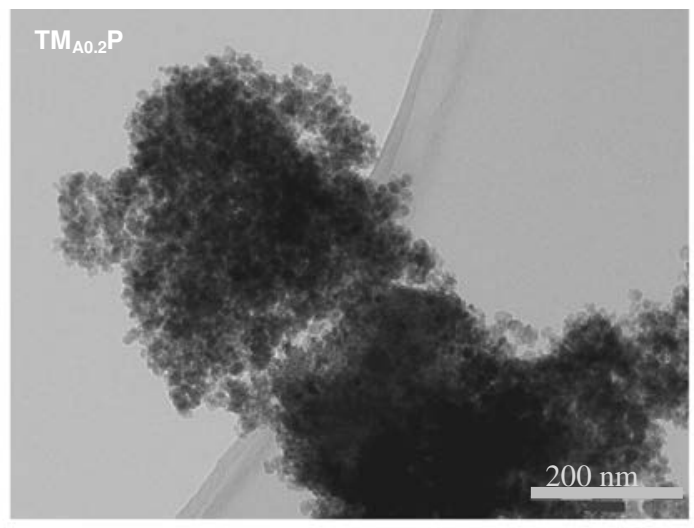

d

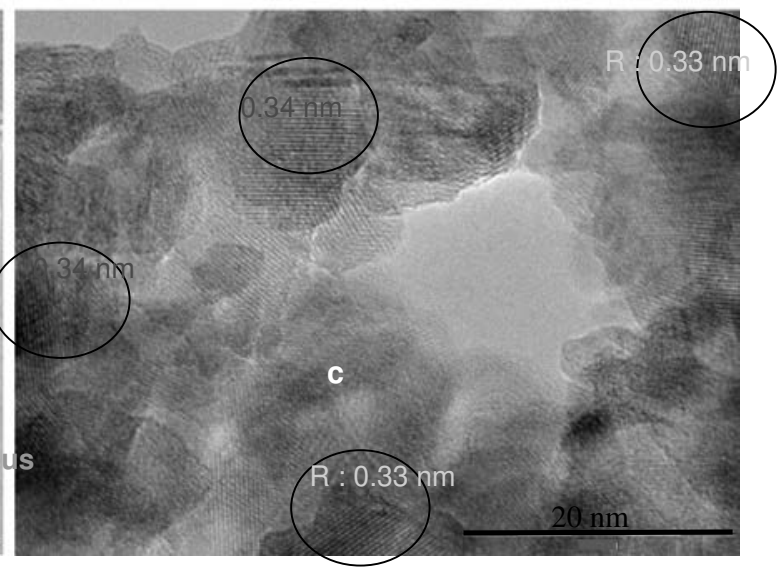

Fig. 8. TEM pictures of the $\mathrm{TM}_{x 0.2} \mathrm{P}$ samples. 

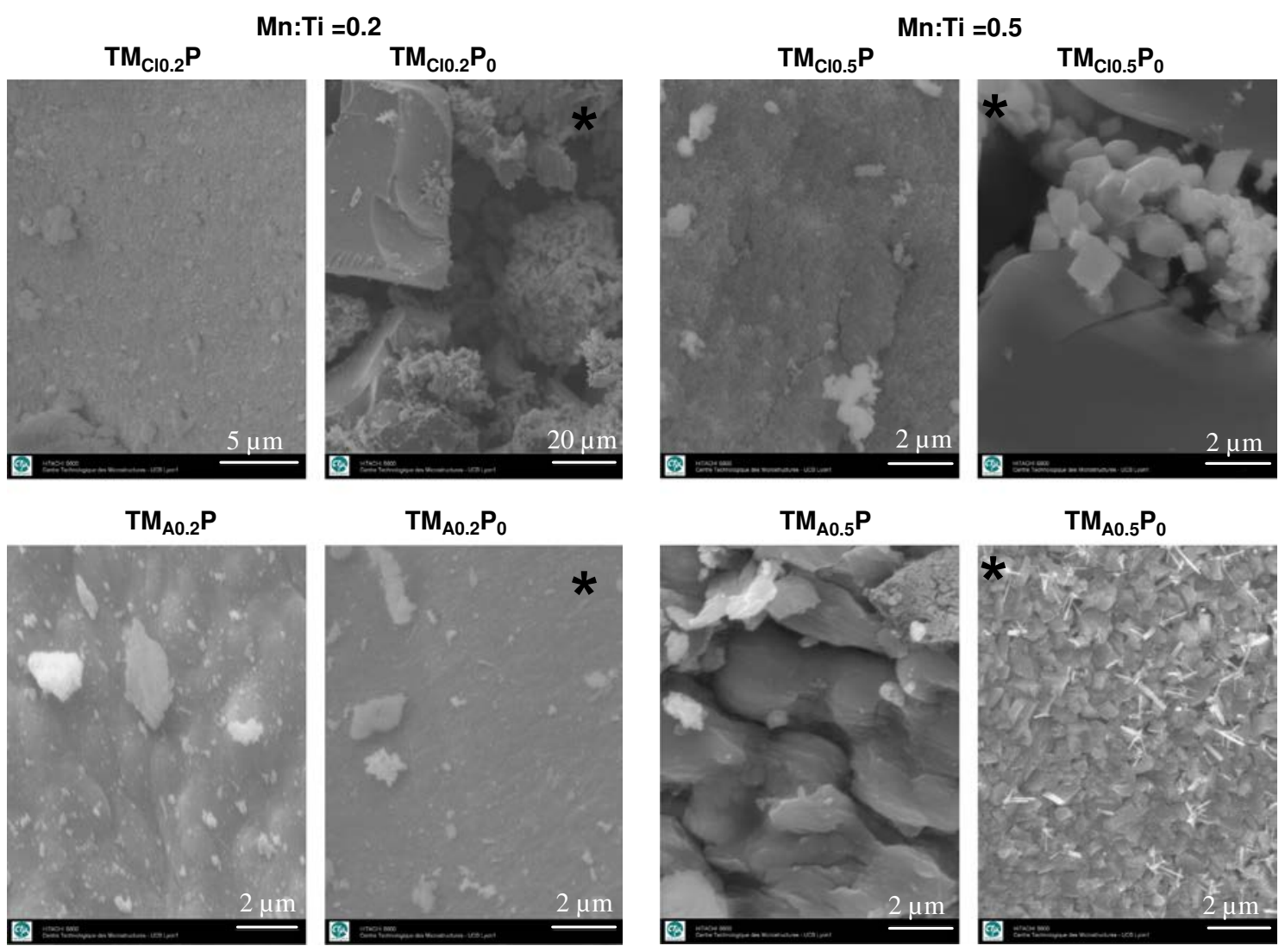

Fig. 9. SEM pictures of the $\mathrm{TM}_{x y} \mathrm{P}$ samples and $\mathrm{TM}_{x} \mathrm{P}_{0}$ samples.

a

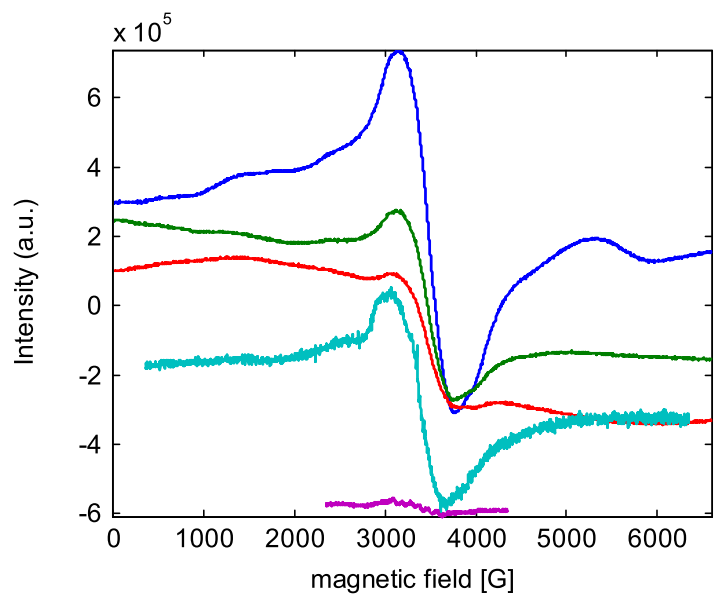

C

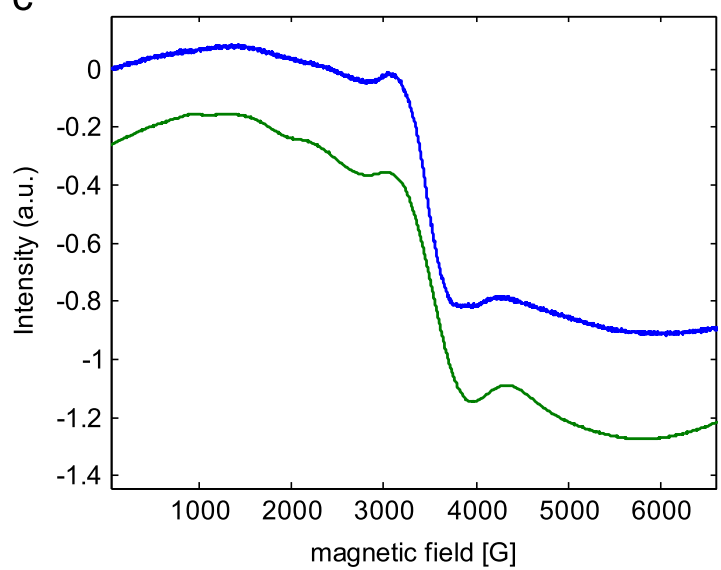

b

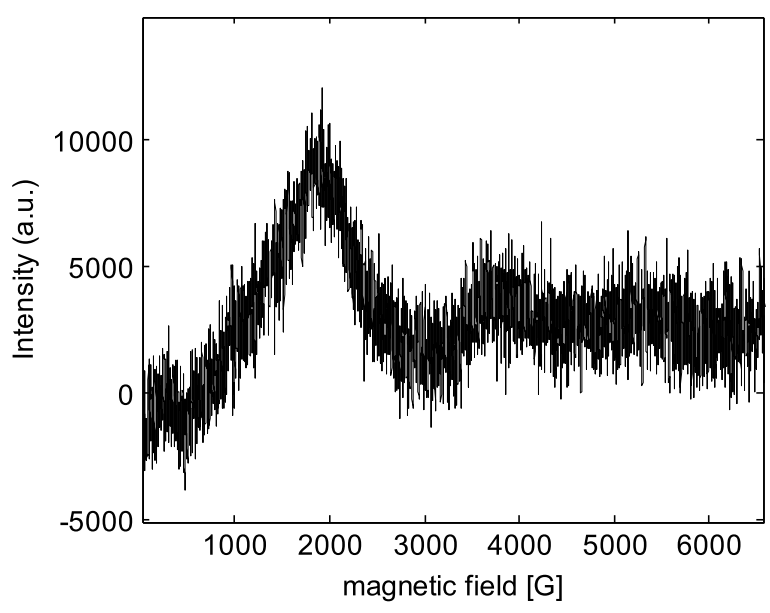

d

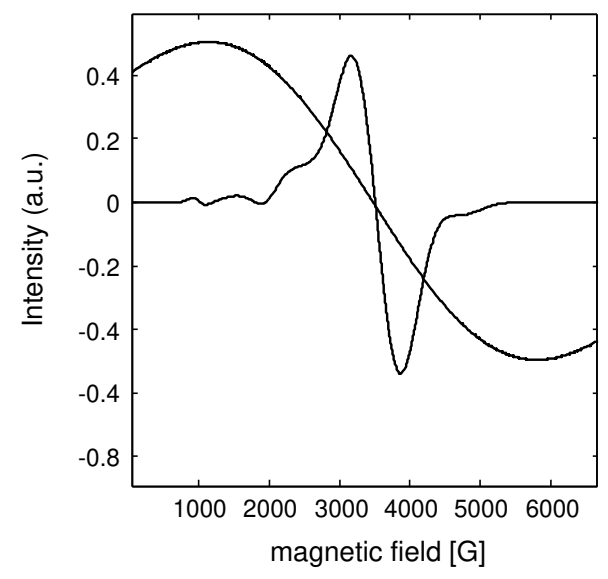

Fig. 10. EPR spectra of the $\mathrm{TM}_{\mathrm{Cl} 0.2} \mathrm{P}$ sample. 


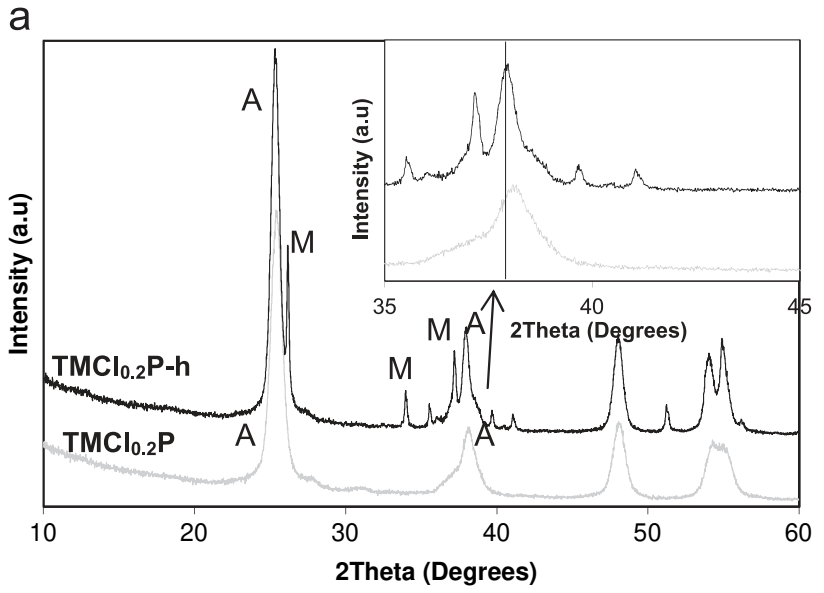

b

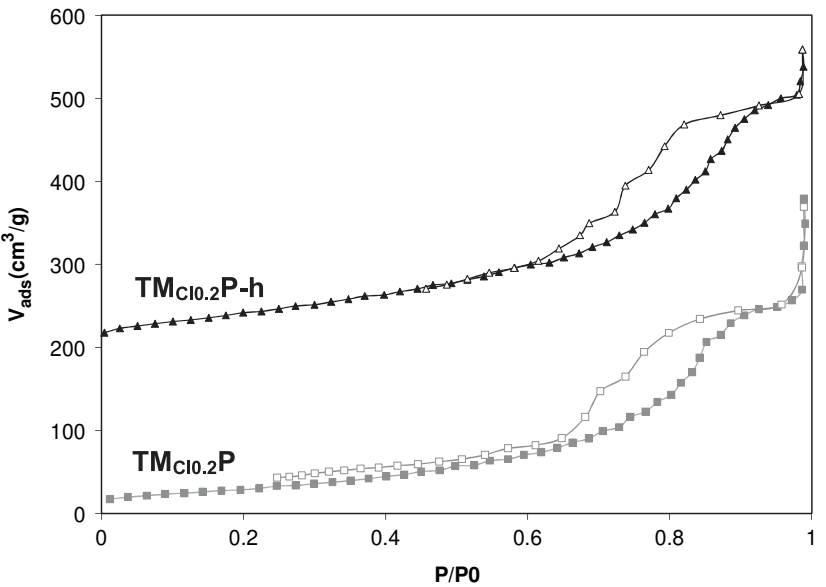

C

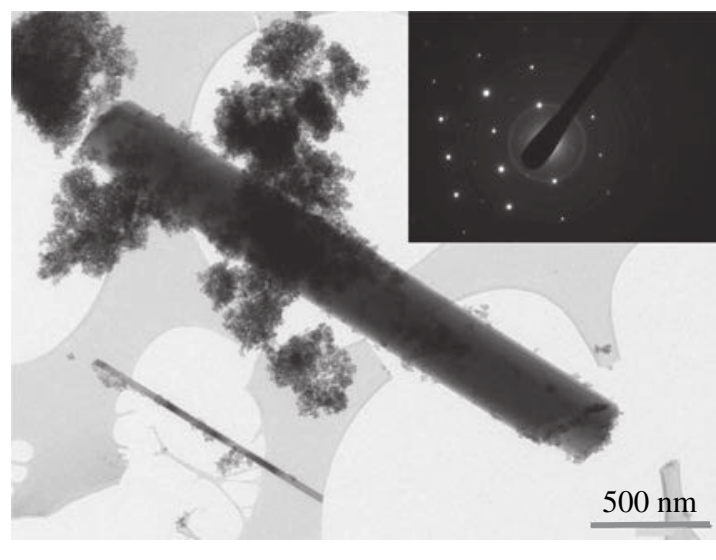

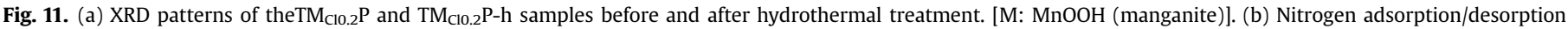
isotherms of theTM $\mathrm{Cl}_{\mathrm{ClO} .2} \mathrm{P}$ and $\mathrm{TM}_{\mathrm{Cl} .2 .} \mathrm{P}-\mathrm{h}$ samples. (c) TEM picture and electronic diffraction pattern of the sample TM $\mathrm{ClO}_{2 .} \mathrm{P}-\mathrm{h}$ after hydrothermal treatment.

In conclusion, these results revealed that:

- (i) most of the manganese (ca. 70\%) was present as Mn(IV) in a cluster type environment, localized outside the titania crystals with strong interaction.

- (ii) some manganese (ca. 30\%) was also present as Mn(IV) at the outer surface of the $\mathrm{TiO}_{2}$ crystals, but with low interaction.

- (iii) only a very limited fraction of the manganese was localized inside the $\mathrm{TiO}_{2}$ lattice in the form of $\mathrm{Mn}^{2+}$. It is likely that $\mathrm{Ti}^{4+}$ had substituted for some $\mathrm{Mn}^{2+}$, as already reported in the literature $[58,59]$.

\subsection{Hydrothermal stability}

The hydrothermal stability of the mesoporous samples initially pre-treated at $450{ }^{\circ} \mathrm{C}$ in dry air was then examined after further treatment in water at $200{ }^{\circ} \mathrm{C}$ for $24 \mathrm{~h}$ (Fig. 11). XRD patterns (Fig. 11a) revealed some significant modifications of the crystalline structure of manganese oxide with the formation of a well crystallized $\mathrm{MnOOH}$ manganite phase (M, ICDD no. 041-1379). This observation is probably the same as the detection of manganese as manganite in natural waters [69]. Furthermore, the anatase phase was even more crystallized after hydrothermal treatment. The shift of the $\left(\begin{array}{lll}0 & 0\end{array}\right)$ reflection line toward lower angles can be explained by the expulsion of the manganese from the anatase lattice.
The textural properties of the solids were also shown to be slightly modified (Fig. 11b and Table 1 ) where the specific surface area increased for the $\mathrm{MnCl}_{2} \cdot 4 \mathrm{H}_{2} \mathrm{O}$ precursor.

Finally, the TEM images and the associated electron diffraction patterns confirmed the high degree of crystallization of the manganese phase (Fig. 11c). The same evolution was observed for the two manganese precursors.

\section{Discussion}

The study of the influence of the block copolymer and manganese precursor during the one pot elaboration of manganese oxide supported on mesoporous titanium dioxides revealed several key points. First, the synthesized $\mathrm{Mn}-\mathrm{Ti}-\mathrm{O}$ solids exhibited a specific surface area ca. $100 \mathrm{~m}^{2} \mathrm{~g}^{-1}$, a pore volume in the range of $0.3-$ $0.4 \mathrm{~cm}^{3} \mathrm{~g}^{-1}$ and an average pore size ca. $11 \mathrm{~nm}$. In fact, the addition of manganese led to an increase in the average pore size from 9 to $11 \mathrm{~nm}$, as reported earlier [44].

Second, the introduction of a manganese salt inside the titaniaprecursor sol modified the organization of this sol and led to a disordered mesoporous structure, where the anatase crystallization was lower and/or the manganese oxide crystallization was strongly delayed, compared to the pure phases. Combining the different characterization results, we conclude that manganese oxide is barely crystalline. Furthermore, the modifications induced by the manganese salt appeared to depend on the nature of the counter anion. 
Third, no manganese oxide crystallization was observed at $0.2 \mathrm{Mn}$ :Ti molar ratio, when $\mathrm{MnCl}_{2} \cdot 4 \mathrm{H}_{2} \mathrm{O}$ precursor was used. This phenomenon had already been observed in previous work dealing with the synthesis of mixed $\mathrm{Mn}$ /Ti oxides via sol-gel with the incorporation of manganese into the anatase lattice $[16,18,19,70-72]$. Upon synthesis of a mesoporous $\mathrm{Mn} / \mathrm{Ti}$ oxide, it was suggested that manganese oxide had covered the titania crystals as a result of the interactions between the $\mathrm{Mn}^{2+}$ cations and the block copolymer [44], and this hypothesis obviously applied in our study. In fact, the $\mathrm{Mn}_{2} \mathrm{O}_{3}$ bixbyite phase crystallization was further delayed as the proportion of block copolymer was increased. The block copolymer acted as a ligand for the $\mathrm{Mn}^{2+}$ cations forming some complexes and completely modifying the interactions with the titania-precursor sol. As a result, the localization of manganese oxide at the outer surface of the titania crystals was favoured. In turn, the mesoporous structure of the anatase phase was maintained. The possible formation of an amorphous $\mathrm{MnO}_{2}$ shell covering the anatase crystals was confirmed by EPR with the evidence for two kinds of $\mathrm{Mn}$ (IV) populations: a cluster-type $\mathrm{Mn}(\mathrm{IV})$ and isolated $\mathrm{Mn}(\mathrm{IV})$.

We also showed that the block copolymer was essential to obtain a good dispersion of the manganese oxide phase with a very low crystallinity. The coordination of the $\mathrm{Mn}^{2+}$ cations and the polyethylene oxide entities on the block copolymer allowed a high degree of isolation of the manganese species and avoided crystallization of the manganese oxide phase. Previous studies had already shown the importance of these polyethylene oxide blocks on the dispersion of manganese inside a silica matrix [73-75]. In fact, transition metals are known to interact strongly with the hydrophilic part of the block copolymers and form complex micelles [54,56]. However, in the present study, we have demonstrated that the latter phenomenon is dependent on the nature of the manganese salt, due to different interactions between the salt and the block copolymer. The anatase structure was strongly modified when the $\mathrm{Mn}(\mathrm{acac})_{2}$ precursor was used. In fact, a mesoporous Mn-Ti-O "mixed" oxide probably formed and the block copolymer had no impact on the manganese localization. Acetylacetonate is known to chelate titanium, which strongly favours the formation of a solid solution between titanium and manganese.

Finally, further treatment of the solids under hydrothermal conditions modified the solid structure. The mesoporous titania structure was preserved but manganese was expelled from the mesoporous structure and crystallized as manganite $(\mathrm{MnOOH})$ at the outer surface of the titania crystals. Therefore, if such mesoporous $\mathrm{Mn}-\mathrm{Ti}-\mathrm{O}$ mixed oxides were used in the catalytic wet air oxidation process, manganese would rapidly segregate outside the titania crystals as large manganite crystals.

\section{Conclusion}

Mesoporous manganese titanium oxides were successfully synthesized using a modified sol-gel process, involving a titanium alkoxide sol, manganese salt and block copolymer. The mesoporous oxides had a specific surface area ca. $100 \mathrm{~m}^{2} \mathrm{~g}^{-1}$, pore volume of $0.3 \mathrm{~cm}^{3} \mathrm{~g}^{-1}$ and $11 \mathrm{~nm}$ average pore size.

For a $0.2 \mathrm{Mn}$ :Ti molar ratio with the $\mathrm{MnCl}_{2} \cdot 4 \mathrm{H}_{2} \mathrm{O}$ precursor, the block copolymer strongly delayed the manganese oxide crystallization by chelating the $\mathrm{Mn}^{2+}$ cations leading to the formation of an amorphous layer around the anatase crystallites. In turn, with the $\mathrm{Mn}(\mathrm{acac})_{2}$ precursor, manganese species were highly dispersed inside the titania, even without any block copolymer. For a $0.5 \mathrm{Mn}$ :Ti ratio, the $\mathrm{Mn}_{2} \mathrm{O}_{3}$ bixbyite $(\mathrm{Mn}(\mathrm{III}))$ or the $\mathrm{MnO}_{2}$ ramsdellite ( $\mathrm{Mn}(\mathrm{IV})$ ) crystallized at the outer surface of the porous structure. Finally, upon hydrothermal treatment, manganese crystallizes as manganite $(\mathrm{MnOOH})$ at the surface of the titania support, while the titania mesostructure was preserved.

\section{Acknowledgments}

This work was financially supported by the Région RhôneAlpes. The authors gratefully acknowledge the Region RhôneAlpes for the Ph.D. grant awarded to France Schmit for the period 2011-2014.

The authors gratefully acknowledge Florian Molton and Carole Duboc, GHMFL-LCMI, Université Joseph Fourier Grenoble 1, for their help during the EPR experiments.

\section{References}

[1] J.E. Post, Proc. Natl. Acad. Sci. U.S.A 96 (1999) 3447-3454.

[2] X. Tang, J. Chen, X. Huang, Y. Xu, W. Shen, Appl. Catal., B: Environ 81 (2008) 115.

[3] Z.Y. Ding, L. Li, D. Wade, E.F. Gloyna, Ind. Eng. Chem. Res. 37 (1998) 1707-1716.

[4] S.L. Brock, N. Duan, Z.R. Tian, O. Giraldo, H. Zhou, S.L. Suib, Chem. Mater. 10 (1998) 2619-2628.

[5] J.W. Dobereiner, J. Chem. Phys. 28 (1820) 223.

[6] J. Quiroz Torres, S. Royer, J.P. Bellat, J.M. Giraudon, J.M. Lamonier, ChemSusChem 6 (2013) 578-592.

[7] M.A. Sidheswaran, H. Destaillats, D.P. Sullivan, J. Larsen, W.J. Fisk, Appl. Catal. B: Environ 107 (17) (2011) 34-41.

[8] Y. Sekine, Atmos. Environ. 36 (2002) 5543-5547.

[9] F.N. Aguero, A. Scian, B.P. Barbero, L.E. Cadus, Catal. Today 133-135 (2008) 493-501.

[10] Q. Ye, J. Zhao, F. Huo, D. Wang, S. Cheng, T. Kang, H. Dai, Microporous Mesoporous Mater. 172 (2013) 20-29.

[11] F. Liu, S. Zuo, X. Xia, J. Sun, Y. Zou, L. Wang, C. Li, C. Qi, J. Mater. Chem. 1 (2013) 4089.

[12] Y. Du, Q. Meng, J. Wang, J. yan, H. fan, Y. Liu, H. Dai, Microporous Mesoporous Mater. 162 (2012) 199-206.

[13] A.K. Sinha, K. Suzuki, M. Takahara, H. Azuma, T. Nonaka, K. Fukumoto, Angew. Chem. Int. Ed. 46 (2007) 2891-2894.

[14] A.K. Sinha, K. Suzuki, M. Takahara, H. Azuma, T. Nonaka, N. Suzuki, N. Takahashi, J. Phys. Chem. C. 112 (2008) 16028-16035.

[15] T. Garcia, D. Sellick, F. Varela, I. Vazquez, A. Dejoz, S. Agouram, S.H. Taylor, B. Solsona, Appl. Catal., A-Gen 450 (2013) 169-177.

[16] Y.J. Kim, H.J. Kwon, I.S. Nam, J.W. Choung, J.K. Kil, H.J. Kim, M.S. Cha, G.K. Yeo, Catal. Today 151 (2010) 244-250.

[17] J. Li, J. Chen, R. Ke, C. Luo, J. Hao, Catal. Comm 8 (2007) 1896-1900.

[18] Z. Wu, B. Jiang, Y. Liu, W. Zhao, B. Guan, J. Hazard. Mater 145 (2007) 488-494.

[19] B. Jian, Y. Liu, Z. Wu, J. Hazard. Mater 162 (2009) 1249-1254.

[20] M. Pourkhalil, A.Z. Moghaddam, A. Rashidi, J. Towfighi, K.J. Jozani, H. Bozorgzadeh, Catal. Lett. (2013) 184-192.

[21] N. Tang, Y. Liu, H. Wang, Z. Wu, J. Phys. Chem. C 115 (2011) 8214-8220.

[22] Z. Wu, N. Tang, L. Xiao, Y. Liu, H. Wang, J. Colloid Interface Sci 352 (2010) 143.

[23] H.J. Ulrich, A.T. Stone, Environ. Sci. Technol 23 (1989) 421-428.

[24] B. Nowack, A.T. Stone, J. Phys. Chem. B 106 (2002) 6227-6233.

[25] C.S. Mc Ardell, A.T. Stone, J. Tian, Environ. Sci. Technol 32 (1998) (29323-2930).

[26] J. Liu, C. Yu, P. Zhao, G. Chen, Appl. Surf. Sci 258 (2012) 9096.

[27] F. Arena, C. Italiano, A. Raneri, C. Saja, Appl. Catal., B: Environ 99 (2010) $321-328$.

[28] L. Kong, W. Wei, Q. Zhao, J.Q. Wang, Y. Wan, ACS Catal 2 (2012) 2577-2586.

[29] Y. Yao, C. Xu, S. Yu, D. Zhang, S. Wang, Ind. Eng. Chem. Res. 52 (2013) $3637-3645$

[30] H. Liang, H. Sun, A. Patel, P. Shukla, Z.H. Zhu, S. Wang, Appl. Catal., B: Environ 127 (2012) 330-335

[31] X. Li, X. Lu, Y. Meng, C. Yao, Z. Chen, J. Alloys Compd. 562 (2013) 56-63.

[32] W. Wei, X. Cui, W. Chen, D.G. Ivey, Chem. Soc. Rev. 40 (2011) 1697-1721.

[33] J. Yuan, K. Laubernds, Q. Zhang, S.L. Suib, J. Am. Chem. Soc. 125 (2003) 4966

[34] J. Luo, S.L. Suib, Chem. Commun. 11 (1997) 1031.

[35] Z.R. Tian, W. Tong, J.Y. Wang, N.G. Duan, V.V. Krishnan, S.L. Suib, Science 276 (1997) 926.

[36] Y. Zhang, Y. Yang, Y. Zhang, T. Zhang, M. Ye, Appl. Catal., B: Environ 127 (2012) $182-189$.

[37] F. Polzer, S. Wunder, Y. Lu, M. Ballauff, J. Catal. 289 (2012) 80-87.

[38] Z. Zhao, J. Liu, F. Cui, H. Feng, L. Zhang, J. Mater. Chem. 22 (2012) 9052.

[39] X. Xiao, S.P. Sun, M.B. Mc bride, A.T. Lemley, Environ. Sci. Pollut. Res. 20 (2013) $10-21$.

[40] R. Zhai, Y. Wan, L. Liu, X. Zhang, W. Wang, J. Liu, B. Zhang, Water Sci. Technol 65 (2012) 1054.

[41] F. Jiao, H. Frei, Energy Environ. Sci 3 (2010) 1018-1027.

[42] M.M. Najafpour, A.N. Moghaddam, New. J. Chem. 36 (2012) 2514-2519.

[43] K. Liu, M. Zhang, K. Shi, H. Fu, Mater. Lett. 59 (2005) 3308-3310.

[44] M. Xue, L. Huang, J.Q. Wang, Y. Wang, L. Gao, J.H. Zhu, Z.G. Zou, Nanotechnology 19 (2008) 185604. 
[45] E.A. Belaya, V.V. Viktorov, Inorg. Mater 44 (2008) 62-66.

[46] R. Arroyo, G. Cordoba, J. Padilla, V.H. Lara, Mater. Lett. 54 (2002) 397-402.

[47] M. Valigi, A. Cimino, J. Solid State Chem 12 (1975) 135-143.

[48] M. Valigi, D. Cordischi, D. Gazzoli, V. Indovina, J. Inorg. Nucl. Chem 38 (1976 1249-1253.

[49] J.M. Gallardo-Amores, T. Armaroli, G. Ramis, E. Finocchio, G. Busca, Appl. Catal, B: Environ 22 (1999) 249-259.

[50] J.P. Xu, J.F. Wang, Y.B. Lin, X.C. Liu, Z.L. Lu, L.Y. Lv, F.M. Zhang, Y.W. Du, J. Phys D: Appl. Phys 40 (2007) 4757-4760.

[51] Y.B. Kang, H.G. Lee, ISIJ Int. 11 (2005) 1543-1551.

[52] J.P. Xu, S.B. Shi, L. Li, J.F. Wang, L.Y. Lv, F.M. Zhang, Y.W. Du, J. Phys. Chem. Solids 70 (2009) 511-515.

[53] G.W. Zhou, Y.S. Kang, Mater. Sci. Eng., C 24 (2004) 71-74.

[54] C. Albayrak, N. Ozkan, O. Dag, Langmuir 27 (2011) 870-873.

[55] G.J. de A.A. Soler-Illia, C. Sanchez, New J. Chem. 24 (2000) 493-499.

[56] C. Albayrak, A. Cihaner, O. Dag, Chem. Eur. J 18 (2012) 4190-4194.

[57] A.A. Ismail, D.W. Bahnemann, L. Robben, V. Yarovyi, M. Wark, Chem. Mater. 22 (2010) 108-116.

[58] G.-Q. Qu, Spectrochim. Acta, Part A 68 (2007) 905-907.

[59] Z.V. Saponjic, N.M. Dimitrijevic, O.G. Poluektov, L.X. Chen, E. Wasinger, U. Welp, D.M. Tiede, X. Zuo, T. Rajh, J. Phys. Chem. B, 110 (2006) 25441-25450.

[60] M.I. Zaki, M.A. Hasan, L. Pasupulety, K. Kumari, New J. Chem. 22 (1998) 875-882.

[61] A.L. Shugarman, Dissertation of California Institute of Technology, Autoxidation of manganese(II) $\beta$ diketonate, Pasadena, US, 1968.
[62] A. Dassler, A. Feltz, J. Jung, W. Ludwig, E. Kaisersberger, J. Therm. Anal 33 (1988) 803-809.

[63] K.S.W. Sing, Pure Appl. Chem. 54 (1982) 2201-2218; M. Thommes, Chem. Ing. Tech. 82 (2010) 1059-1073.

[64] J. Ye, W. Liu, J. Cai, S. Chen, X. Zhao, H. Zhou, L. Qi, J. Am. Chem. Soc. 133 (2011) 933-940.

[65] B. Choudhury, A. Choudhury, Curr. Appl. Phys. 13 (2013) 1025-1031.

[66] Q. Tanga, X. Huang, Y. Chen, T. Liu, Y. Yang, J. Mol. Catal. A: Chem 301 (2009) 24-30.

[67] H. Kaftelen, M. Tuncer, S. Tu, S. Repp, H. Goçmez, R. Thomann, S. Weber, E. Erdem, J. Mater. Chem. A 1 (2013) 9973.

[68] K.C. Heo, C.I. Ok, J.W. Kim, J. Korean Phys. Soc. 47 (2005) 861-865.

[69] M. Ramstedt, Chemical Processes at the Water-Manganite $(\gamma-\mathrm{MnOOH})$ Interface, Dissertation Umea University, 2004.

[70] H. Li, D. Wang, H. Fan, T. Jiang, X. Li, T. Xie, Nano Res 4 (2011) 460-469.

[71] L. Zhang, D. He, P. Jiang, Catal. Commun 10 (2009) 1414-1416.

[72] N. Nishimura, J. Tanikawa, M. Fujii, T. Kawahara, J. Ino, T. Akita, T. Fujino, H. Tada, Chem. Commun (2008) 3564-3566.

[73] B. Ammundsen, G.R. Burns, D.J. Jones, J. Rozière, J. Sol-Gel Sci. Technol 8 (1997) $331-336$.

[74] B. Ammundsen, D.J. Jones, J. Rozière, G.R. Burns, Chem. Mater. 9 (1997) 3236-3246.

[75] H.S. Lee, W.H. Kim, J.H. Lee, D.J. Choi, Y.-K. Jeong, J.H. Chang, J. Solid State Chem 185 (2012) 89-94. 